\title{
Service Quality and Profitability of Banks: A Study of Selected Nigerian Bank
}

\author{
Meshach G. Goyit \\ Department of Business Administration \\ Faculty of Management Sciences \\ University of Jos, Jos-Nigeria \\ goyitm@yahoo.com
}

\author{
Teresa M. Nmadu Phd \\ Department of Business Administration \\ Faculty of Management Sciences \\ University of Jos, Jos-Nigeria \\ nmadut@yahoo.uk.com
}

\begin{abstract}
The service sector of the economy has become a major role in the economies of most nations of the world and citizens living in such economies are living in increasingly service based economies. This is because the service sector plays a dominant role in creating value in such economies and by extension, the purchasing patterns of consumers and managerial decisions of the providers of these services to a large extent are influenced by activities of players in the sector. For the service sector to maintain dominance in the economic sector, the quality of services being provided should meet or exceed customers' expectations. This research work seeks to assess the impact of the quality of banking services on the profitability of banks. To study this, we postulated three research hypotheses, relied on secondary data using the SPSS package, analysed data through the regression analysis and found out that there is no significant relationship between volume of Deposit and investment in service quality by banks in Nigeria, there is no significant relationship between investments in service quality and volume of turnover by banks and that there is no significant relationship between investments in banks' service quality and the profitability of banks in Nigeria. The absence of a clear strong relationship between service quality improvements and profitability in the Nigerian banking sector is an indication that banks are not really showing improvements in the provision of banking services that would draw the attention of customers.Based on the findings, we conclude that to be able to achieve repeat purchase by customers in the increasing competitive banking business, banks should organize their operations according to the needs expressed (or in several cases even not expressed) by their customers.
\end{abstract}

Keywords: Service, quality, Service quality and profitability

\section{INTRODUCTION}

In most economies of the world, the service sector of the economy has assumed a major role. As a result there has been a dramatic surge in the growth of the service sector as asserted by Kotler (2003) when he posited that services account for $74 \%$ of U.S.A's GDP, nearly $60 \%$ of personal consumption and $82 \%$ of total employment. The service sector represents $76 \%$ of the activity in the USA and $65 \%$ in Europe. He also asserted that the service sector has grown faster in the world economy, making up a quarter of the value of all international trade. But before now, agriculture was the prominent industry that contributed most to national income even in the developed countries.

For the service sector to maintain this dominance, the quality of services should meet or exceed customers' expectations. Quality portents an embodiment of value(s) that is/are capable of meeting standard expectations or requirements. This explains why Crosby (1979) sees quality as "conformance to requirement". This has led to the conception that we need to define service quality on the basis of the requirements or expectations of the customers. In this regard, a customer's expectations of service quality and the overall impression the customer has and experiences with the service and the service provider forms the basis for the service being regarded as of quality. In view of this, Khan, and Mahapatra, (2009) posited that it is imperative for the operators in the sector to seek for ways of improvement in the delivery of services which they provide. Thus, service providers who seek improvements in profits ought to monitor and employ means of improvements in service quality on a continuous basis.

Perhaps, it is in the bid to improve the management of this sector that institutions providing financial services are rapidly changing their strategies/approaches and manner in which these services are being provided. One of such approaches or strategies is improvement in service quality by business executives which is being practiced globally. 
In Nigeria, the concept of service quality is largely a new phenomenon since the Nigerian market is largely dominated by primary goods. As a result quality concerns emerged only more visible with the introduction of Structural Adjustment Programme (SAP) in July, 1986 (Uche, 2001). This phenomenal shift, led to the concern for improvement in service quality particularly in the banking sector. This new spirit brought about competition which meant that banks had little or no choice than to intensify the placement of increased emphasis on service quality in order to achieve customer satisfaction and by extension to create new markets, protect and develop market shares and survive the competition or for long-term profitability, survival and success in such a highly competitive industry.

However, the reality of the scenario in the Nigerian banking industry does portray the contrary as studies by scholars such as Olaleke (2010) indicated that poor service quality is a common feature. Also, Woldie (2003) also found great level of dissatisfaction by many people with the quality of services that are provided by Nigerian banks. This may be evidenced by the seemingly long queues in the banking halls and at ATM locations, unnecessary delays in resolving complaints, the unusually long period required before interbank cheques are cleared and tendencies of customers switching between products and banks. Since much of the studies on service quality programmes and their impact on customer attitudinal changes are foreign based or conducted in Europe, America or other more advanced economies; there is the need to assess the impact of service quality improvement programmes on the choice of banks and banking services by Nigerian bank customers.

\section{ReSEARCh Problem}

Where an industry is highly competitive, an understanding of the needs of the customers and other stakeholders becomes a significant success/growth or productivity factor. This has necessitated the move from product centeredness to customer centeredness in marketing. This explains why Kotler (2003) asserted that delivering superior services has become one of the most important ways to gain superior profitability.

Banks worldwide provide homogenous services to their clients and that as a result of this uniqueness; many banks are able to quickly match competitive innovativeness of competitors and innovators. However, customers still can perceive differences in the quality of services these banks render. This presupposes that service quality invariably plays a significant role in bringing about customer loyalty, satisfaction and profitability. In this respect banks seek to develop reputation for superior performance especially, in faster and better answering of enquiries, on-time delivery, quicker resolution of complaints. Although, many banks in Nigeria have investments in service programmes that should provide superior services, yet service satisfaction leaves much to be desired. This is evidenced by the long queues and long hours in the banking halls coupled with occasional ineffectiveness of automated teller machines (ATMs). This is affirmed by the studies of Olaleke (2010) who argued that Nigerian banks have been found to be characterised by poor service quality, Cuffe (2008) when he found out that certain Nigerian banks employ quality operations while others do not and Woldie (2003), when he opined that most people are dissatisfied with the quality of services that are provided by Nigerian banks,

It is apparent that customers who receive poor treatments will perceive the institution in bad light and this can impact negatively on its profitability. The scenario where the importance of improvement in service quality is marred by incidences of customer complaints, handling of complaints, switching from one bank to another by customers, closure of accounts, etc. creates great concern to scholars and practitioners alike.

From the foregone it is therefore necessary to examine the attributes consumers use in their assessment of service quality which can enhance profitability and overall bank performance. The scenario where Nigerian banks declare huge profits annually in the face of poor quality operations leaves many questions unanswered in the minds of researchers, students and actors in the banking industry as to whether there is any causality between service quality and profitability in the industry. This study seeks to examine the relationship between improvements in service quality and profitability in the Nigerian banking sector.

\section{RESEARCH QUESTIONS AND OBJECTIVES}

This research work seeks to assess the impact of the quality of banking services on the profitability of banks. In order to help achieve this broad research goal, we hereby state the following specific objectives: 
i. To assess the influence of investment in service quality on turnover of banks in Nigeria.

ii. To evaluate the influence of investment in service quality on profitability of banks in Nigeria

Based on the topic and the problem, we want to find answers to these questions:

i. Is there any relationship between investments in service quality and profitability of banks?

ii. Is there any relationship between turnover and investments in service quality by Nigerian banks?

\section{Hypothesis I}

$\mathbf{H}_{\mathbf{0}}$ There is no significant relationship between investment in service quality and volume of deposits of banks.

\section{Hypothesis II}

$\mathbf{H}_{\mathbf{0}}$ There is no significant relationship between investments in banks' service quality and turnover of banks in Nigeria.

\section{Hypothesis III}

$\mathbf{H}_{\mathbf{0}}$ There is no significant relationship between investments in banks' service quality and the profitability of banks in Nigeria.

\section{REVIEW OF LITERATURE}

\subsection{Impact of Service Quality on Bank Profitability}

In today's banking environment, banks' profitability levels have been compressed due to increased competition and spread reductions. Banks once relied upon products to make their profit margin in a highly regulated industry, and the customers basically were on the sidelines, but today banks are driven by customers who demand service quality (Stone, 1995). Parasuraman, Zeithaml and Berry (1988) observed that quality of service is very important in separating competing businesses in the retail sector as well as in banking. Banks seeking to maximize profitability have come to realize that good quality helps a bank obtain and keep customers and poor quality will cause customers to leave a bank. It is well and good to recognize this need for implementing the practice of service by all of its employees, but how to carry out the practice and convince the bank's employees of this need is another matter. Lewis (1993) found that service quality was one of the most effective means of establishing a competitive position and improving profit performance. To establish a competitive position, it was noted by Hall (1995) that banks must measure and determine their level of service quality, if they desire to keep their customers and satisfy their needs. In addition, it should also be pointed out that the only means through which service can be measured is to ask the service recipients. Reinforcing this important research, there have been a large number of researchers who identify service quality as a primary means of providing a competitive advantage to banks, and according to Soteriou and Stavrinides (1997) the importance of service quality has been documented in numerous studies. They found that the advantage was readily identifiable through their research. In some specific studies in four U. S. banks, Morrall (1994) found that the implementation of service quality at First Chicago Bank, Compass Bank, Marquette Bancshares, Inc., and Wachovia Bank gave them a substantial advantage over their competitors. Once banks implemented service quality, their profitability was also noticeably improved.

\subsection{Measurement of Banks' Profit}

Banks once relied upon products to make their profit margin in a highly regulated industry, and the customers basically were on the sidelines, but today banks are driven by customers who demand service quality. Parasuraman, Zeithaml and Berry (1988) observed that quality of service is very important in separating competing businesses in the retail sector as well as in banking. Lewis (1993) also found that service quality was one of the most effective means of establishing a competitive position and improving profit performance.

To establish a competitive position, it was noted by Hall (1995) that banks must measure and determine their level of service quality, if they desire to keep their customers and satisfy their needs. In addition, it should also be pointed out that the only means through which service can be measured is to ask the service recipients. Reinforcing this important research, there have been a large number of 
researchers who identify service quality as a primary means of providing a competitive advantage to banks, and according to Soteriou and Stavrinides (1997) the importance of service quality has been documented in numerous studies because one of the principal reasons for customers to leave an organisation is poor service delivery. Similarly, Avkiran (1994) indicated that a telephone study in Australian revealed poor service to the customer as the most likely reason for customers to consider moving their banking relationships.

Profitability in the banking industry and every business enterprise is quite a significant success/growth indicator. This is so because profits reassure depositors/ stakeholders of the safety of their investments, of the competence of management and adequacy of capital base which together provide good defence against risk which is inherent in the banking industry. Banks with low profits can hardly venture into new markets, new programmes or develop/innovate packages for their customers and the business. Consequently, firms need to analyse their performances from the viewpoint of their profits.

\subsection{Factors Influencing Bank Profitability}

Many studies have introduced some useful variables in the profit function of commercial banks to shed light on key factors that make a difference in bank profits. Such studies are not without ambiguity especially with regard to the measurement of the variables and the results reported thereafter. However there is general agreement that bank profitability is a function of internal and external factors. Koch (1995) observed that the performance differences between banks indicate differences in management philosophy as well as differences in the market served. Athanasoglou, Brissimis and Delis (2006) concurred and argued that profitability is a function of internal factors that are mainly influenced by a bank's management decisions and policy objectives such as the level of liquidity, provisioning policy, capital adequacy, expense management and bank size, and the external factors related to industrial structural factors such as ownership, market concentration and stock market development and other macro-economic factors.

Several studies (Elyor (2009), Uzhegova (2010) have used Capital adequacy, Asset quality, Management efficiency, Earnings performance and Liquidity (CAMEL) to examine factors affecting bank profitability with success. The US Federal Deposit Insurance Corporation (FDIC) developed a system for early identification of problems in banks' operations (Uzhegova, 2010). Some alternative bank performance evaluation models have been proposed.

Several scholars have established some level of prediction in relation to the influence of service quality on profitability of banks while yet others have found the contrary. For example, Grant (1998) reported that studies have found a positive correlation between customer satisfaction and stock market returns; Zeithaml, Parasuraman and Berry, (1993) advocate that when a company advocates and provides excellent customer service, resulting into excellent customer satisfaction which in turn increases customer's desire to use the supplier's services in the future, thus increasing the company's profitability.

Also, Bolton and Lehman (1999) found out that individual's perceptions of equity in service encounters has been shown to influence repeat service purchase; Bates, Bates and Johnson (2003) posited that a positive relationship exists between improvements in service quality and a company's profitability as evidenced in their studies of companies in the United Kingdom (U.K.), when they found out that better service providers had a significantly better return on equity than the poorer providers.

These findings show that there is a positive relationship between loyalty, favourable attitudinal behavioural intentions such as praise for the company and expressions of preference for the company and its goods and services over others. This is the clear situation when Heskett, Jones, Loveman, Sasser and Schlesinger (1994) in Soteriou and Zenious (1999) concluded among other things that profit and growth are stimulated primarily by customer loyalty. These studies are indications that higher levels of satisfaction lead to customer loyalty and that increasing loyalty helps secure future revenues, reduce the costs of future transactions and those of defective goods and services with the resultant effect of decreasing price elasticity and minimizing the likelihood of customers' defection.

Conversely, there abound results of studies that support the contrary position, that there is lack of evidences to support a link between quality and financial performance, pointing out that evidences pointing to a direct positive linkage between service quality and profitability are anecdotal in nature since many managers were frustrated by the inability of quality improvements to result into 
organizational performance. A typical empirical situation was the study that showed that the British Airways which scored well on customers' satisfaction ironically did performed poor financially compared to relatively low quality carriers such as Ryanair (Palmer, 2005). Anderson, Fornell and Lehman (1992), Passikoff, (1997), Zeithaml, Parasuraman and Malhotra (2002), also did not establish any positive relationship between service quality improvements and corporate profitability.

Due to the great importance of profitability for good functioning of the banking system, authors in this area have postulated theories that could predict some form of relationships between variables. The Market Power (MP) hypothesis posits that the performance of banks is influenced by the market structure of the industry while the Efficiency Structure (ES) hypothesis, on the other hand posits that banks earn high profits because they are more efficient than others. The balanced portfolio theory has also added greater insight into the study of bank by ascribing profitability in the banking industry to policy decisions such as portfolio diversification, portfolio composition, the feasible set of assets and liabilities determined by the management and the unit costs incurred by the bank for producing each component of assets (Nzongang and Atemnkeng, 2006)

The above theoretical analyses show that MP theory assumes that bank profitability is a function of external market factors, while the ES and Portfolio theories largely assume that bank performance is influenced by internal efficiencies and managerial decisions. Due to this, most researchers prefer market structure theories rather than the traditional theory to analyze the profitability of the industry in terms of industry structure.

The literature reviewed could not point particularly to any Nigerian circumstance (s) where profits in the banking sector are linked to the application of service quality programmes by banks. This relationship is a necessary ingredient for bank executives/managers in as much as it will determine the linkage between investments in service quality and profits. Besides, causality with respect to the nature of relationship between quality and profits in other countries is a contentious matter as other findings did prove otherwise.

Also, reviewed literature did not precisely indicate that behavioural patterns of Nigerian bank customers did show any direct relationship with the application of service quality systems in service provision and delivery. Consequently, there is every need for a search towards filling this gap. This level of inadequacy in the current body of knowledge relating to the relationship between investment in service quality and bank profitability within the Nigerian context makes it obvious that the area has not been thoroughly researched. The value of this study will be justified by the empirical research that will attempt to make an important contribution to the body of knowledge and the literature on service quality and bank profitability.

\section{Methodology}

In this study, five banks were randomly selected for the purpose of the study. The study employed Ordinary Least Squares (OLS) regression to examine the aggregate effect of explanatory variables on profitability.

\subsection{Test of Hypothesis I}

To examine the relationship between the dependent variable and explanatory variables as well as the magnitude of the impact of the explanatory variables on the dependent variable, the OLS regression is estimated.

Table1. OLS Regression Results of investment in service quality on volume of deposit of banks from 2006 to 2012

\begin{tabular}{|l|l|l|l|}
\hline Explanatory variables & Expected sign & Coefficient of model & P-value \\
\hline Investment service quality & + & 137.1013 & $0.013^{* *}$ \\
\hline Const. & & $7.88 \mathrm{e}+11$ & 0.135 \\
\hline$R^{2}$ & 0.1246 & & \\
\hline $\mathrm{N}$ (observation) & 35 & & \\
\hline
\end{tabular}

Notes: the value of the standard error is given in parenthesis below the coefficient

estimates where:

*indicates Statistical significant level at $1 \%$

** indicates Statistical significant level at 5\%

*** indicates Statistical significant level at $10 \%$

Dependent variable: Volume of Deposit

International Journal of Managerial Studies and Research (IJMSR) 
The R-square shows a value of 0.1246 for the relationship between the dependent and the independent variable indicating a little contribution to explaining the variance.

From table 1, the P-value of the independent variable is 0.013 while the level of significance is 0.05 . Since the p-value is less than the level of significance, the null hypothesis is not upheld. Therefore, the conclusion is that there is no significant relationship between volume of Deposit and investment in service quality by banks in Nigeria.

\subsection{Test of Hypothesis II}

Table2. OLS Regression Results Of Investment In Service Quality On Turnover Selected Banks In Nigeria From 2006 To 2012

\begin{tabular}{|l|l|l|l|}
\hline Explanatory variables & Expected sign & Coefficient of model & P-value \\
\hline Investment service quality & + & 12.1069 & 0.120 \\
\hline Const. & & $7.75 \mathrm{e}+10$ & 0.00 \\
\hline$R^{2}$ & 0.1202 & & \\
\hline $\mathrm{N}$ (observation) & 35 & & \\
\hline
\end{tabular}

Notes: the value of the standard error is given in parenthesis below the coefficient

estimates where:

*indicates Statistical significant level at $1 \%$

** indicates Statistical significant level at 5\%

*** indicates Statistical significant level at $10 \%$

Dependent variable: Turnover

The R-square shows a value of 0.1202 for the relationship between the dependent and the independent variable indicating a little contribution to explaining the variance.

Our finding from table 2 shows that the P-value of the independent variable is 0.120 while the level of significance is 0.05 . Here, the p-value is greater than the level of significance, thus there is sufficient reason to uphold the null hypothesis. Therefore, the conclusion is that there is no significant relationship between investments in service quality and volume of turnover by banks.

The result is consistent with Lynn (2002) in a study, Turnover's Relationships with Sales, Tips and Service across Restaurants in a Chain. This study found that turnover declined among high volume restaurants but not among low volume restaurants. Interestingly, the opposite pattern was observed for the effects of tip percentages on turnover - turnover declined as tip percentages increased among low volume restaurants but not among high volume restaurants. Since server income increases with both sales and tip percentages, this conflicting pattern of results is puzzling. Perhaps servers in high volume restaurants focus on sales as the major determinant of their tip incomes while servers in low volume restaurants focus on tip percentages as the major determinant of their tip incomes.

\subsection{Test Of Hypothesis III}

Table3. OLS Regression Results of investment in service quality on profitability selected banks in Nigeria from 2006 to 2012

\begin{tabular}{|l|l|l|l|}
\hline Explanatory variables & Expected sign & Coefficient of model & P-value \\
\hline Investment service quality & + & 2.303569 & $0.063^{* * *}$ \\
\hline Const. & & $1.81 \mathrm{e}+10$ & 0.002 \\
\hline$R^{2}$ & 0.0474 & & \\
\hline $\mathrm{N}$ (observation) & 35 & & \\
\hline
\end{tabular}

Notes. the value of the standard error is given in parenthesis below the coefficient

estimates where:

*indicates Statistical significant level at $1 \%$

** indicates Statistical significant level at 5\%

*** indicates Statistical significant level at 10\%

Dependent variable: Profitability 
The R-square shows a value of 0.0474 for the relationship between the dependent and the independent variable indicating a substantial contribution to the dependent variable.

From table 3, the P-value of the independent variable is 0.063 while the level of significance is 0.05 . Here, the p-value is more than the level of significance; there is sufficient reason to uphold the null hypothesis. Therefore, the conclusion is that there is no significant relationship between investments in banks' service quality and the profitability of banks in Nigeria.

This result is inconsistent with Becser, (2007), as well as the findings of Fitzsimmons and Fitzsimmons (2004); ISO Survey (2005); EuroStat (2007) and Palánkai (2007) where they all affirmed that there is positive relationship between performance (profitability) and investment in service quality. Also the findings of Guru, Stauton and Balalashanmugam (2002) also show that efficient management is among the most important factors that explain high bank profitability. There is no connection between quality and performance of Nigerian banks. Numerous researchers by Cronin, Brady and Hult (2000) and Olorunniwo, Hsu and Udo 2006,) verified that higher service quality results in a higher performance of the organization. This however is in not in conformity with our finding. However, the findings of Ittner and Larcker (1998) conform to our finding.

\section{CONCLUSION AND RECOMMENDATIONS}

Competition among service providers is increasing and it extends across borders and continents due to globalization. To be able to achieve repeat purchase by customers in the increasing competitive banking business, service providers should organize their operations according to the needs expressed (or in several cases even not expressed) by their customers. They should provide services and products to meet or even exceed customers' expectations. This implies they should aim at quality. This applies not only to bank service providers but to all and sundry in the service sector - to organizations providing social services (for example, educational or medical services), to personal services (hairdressers, for instance), to production services (for example, financial services), to distributive services, etc. In the service sector, reactions related to quality appear very quickly as a result of the close connection to customers, which affects organizations even more strongly due to the strong competition. Therefore, quality improvement is the prerequisite for survival and of profiting from competitive advantages.

However, absence of a clear strong relationship between service quality improvements and profitability in the Nigerian banking sector is an indication that banks are not really showing improvements in the provision of banking services that would draw the attention, This probably is responsible for the lack of apathy in the utilization of banking services by customers and the frequent cases of loss of huge sums of money to natural disasters such as fire.

\section{REFERENCES}

Athansasoglou, P., Brissimis, S. \& Delis, M. (2006). Bank-Specific, Industry-Specific and Macroeconomic Determinants of Bank Profitability. Journal of International Financial Markets, Institutions and Money. 121-136.

Avkiran, N K. (1994), "Developing an Instrument to Measure Customer Service Quality in Branch Banking," International Journal of Bank Marketing, 12/6, 10-18.

Bates, K., Bates, H. and Johnson, R. (2003). Linking Services to Profit: The Business Case for Services Excellence. International Journal of Science Industry Management. Iv (2) Pp. 173 183. In Palmer, A. (2005). Principles of services marketing. 4th ed. New York. McGraw - Hill

Becser, N. (2007). Improving Service Quality in Retail Trade, Corvinus University of Budapest Management and business Administration Doctoral Program

Bolton, R. N. and Lehman, K. N., (1999). A dynamic model of customers' usage of services: Usage as an Antecedent and consequence of satisfaction. Journal of Marketing Research 36(2) Pp. 171 186.

Cronin J. J., Brady, M. K. and Hult, G. T. M. (2000). Assessing the Effects of Quality, Value, and Customer Satisfaction on Consumer Behavioral Intentions in Service Environments. Journal of Retailing, 76(2), 192-218.

Crosby, P.B., (1979). Quality is Free: the Art of Making Quality Certain, McGraw- Hill, New York. Cuffe, A. (2008) Nigerian banks: Fasten your belts, high growth and bumpy tide ahead; initiating coverage of the sector andrew.j.cuffe@jpmorgan.com. Retrieved: 30th December, 2009. 
Elyor, S. (2009). Factors Affecting the Performance of Foreign Banks in Malaysia. A Thesis Submitted in Partial Fulfillment of the Requirements of Universiti Utara Malaysia for the Degree of Master of Science (Banking). October.

EUROSTAT (2007).Europe in figures.EuroStat Yearbook 2006-07., Luxembourg,http://ec.europa.eu/ eurostat.

Fitzsimmons, J.A. and Fitzsimmons, M.J. (2004).Service Management Operations, Strategy, and Information Technology, McGraw-Hill, New York.

Grant, (1998) "Your Customers are Telling the Truth". Fortune, 16 Feb. Pp. 164 - 166.

Guru B, Staunton J, Balashanmugam B (2002). Determinants of commercial banks profitability in Malaysia. University Multimedia Working Papers.

Hall, P. (1995), "The Importance of Measuring Service Quality," Bank Marketing, 27/2 (February), 76.

Heskett, Jones, Loveman, Sasser and Schlesinger (1994)Ittner, C. D. and Larcker, D. F. (1998). Are Nonfinancial Measures Leading Indicators of Financial Performance?An Analysis of Customer Satisfaction. Journal of Accounting Research, Vol. 36 (Supplement), pp. 1-36.

ISO Survey (2005); ISO 9000: Quality Management System, Fundamentals and vocabulary, Khan, M. S. and Mahapatra, S.S. (2009). Services Quality Evaluation in Internet

Banking: An Empirical study in India. International Journal Indian Culture and Business Management Vol. 2 No. 1

Koch, T.W. (1995). Bank Management. 3rd edn. The Dryden Press. London Kotter, P. (2003). Marketing Management (11 ed.), New-Jeresey. Pearson education/Prentice - Hall, Lewis , B . R . ( 1993 ). Service quality: Recent developments in financial services. International Journal of Bank Marketing, Vol. 11, No. 6 , pp. $19-25$.

Lynn, M. (2002). Turnover's Relationships with Sales, Tips and Service across Restaurants in a Chain. Cornell Hotel and Restaurant Administration Quarterly, 37 (3), 24-29.

Morrall, K. (1994), "Service Quality: The Ultimate Differentiator," Bank Marketing, 26 (10) (October), 33-37.

Naceur, S. (2003). The Determinants of the Tunisian Banking Industry Profitability: Panel Evidence. October

Nzongang, T. \& Atemnkeng, J. (2006). Market Structure and Profitability Performance in the Banking Industry of CFA countries: the Case of Commercial Banks in Cameroon

Olaleke, O.O. (2010).Assessing the Relationship Between Service Quality and Customer Satisfaction: Evidence from Nigerian Banking Industry. Journal of Managemenet and Business Research. Vol 10 Issue (Version 1.0). Accessed: 19th January, 2011.

Olorunniwo, F. ,Hsu, M. K. and Udo, G. J. (2006). Service quality, customer satisfaction, and behavioral intentions in the service factory. Journal of Services Marketing, Vol. 20, No. 1, pp. 59-72.

Palánkai, T. (2007).A globálisátalakuláskihívásai - Elkerülhet_k-e akataklizmák?Magyar Tudomány, 2007/2,http://www.matud.iif.hu/07feb/16.html

Palmer, A. (2005). Principles of Services Marketing. (4th ed).Maidenhead McGraw- hill.

Parasuraman, A., Zeithaml, V. A. and Berry, L. L. (1988). A multiple Item Scale for measuring consumer perceptions of service Quality, Journal of Retailing Vol. 64. No. 1 pp. 12 - 37.

Passikoff, R. (1997). The limits of consumer satisfaction. Brand Week 38 (9). 17.Soteriou, A. C. and Stavrinides, Y. (1997), “An Internal Customer Service Quality Data

Envelopment Analysis Model For Bank Branches," International Journal of Operations \& Production Management, 17 Issue 7/8, 780-791.

Soteriou, A. and Zenions, S. A. (1999). Operations, Quality and profitability in the provision of Banking Services. Marketing Scitence Vol. 45. No. 9. Retrieved 24 - 09 - 2008.

Stone, S (1995), "Eureka! What If We Treated Customers As Customers?" Journal for Quality \& Participation, 18 (4) (July/August), 94-97.

Uzhegova, O. (2010). The Relative Importance of Bank-specific Factors for Bank Profitability in Developing Economies 
Woldie, A. (2003). Nigerian Banks - Service Quality. Journal of African Business 1522 - 9076, Vol 2. Accessed16th Jan 2011

Zeithaml, V. A. Berry, L. L. and Parasuraman, A. L. L. (1993). The nature and Determinants of Customer Expectations of Service. Journal of Academy of Marketing Science 21(1) PP.1-12.

Zeithaml, V. A. Parasuraman, A. and Malhotra, A. (2002). Service Quality Delivery Through Websites: A Critical Review of Extent knowledge. Academy of marketing science journal Vol. 30 .

\section{AUTHORS' BIOGRAPHY}

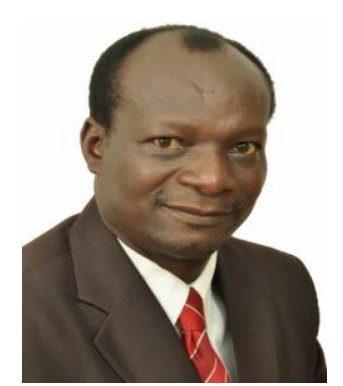

Dr Goyit, Meshach G. holds a PhD in Management from the University of Jos, Nigeria. He is currentlya Senior Lecturer with the Department of Business Administration and Acting Head of the Department of Business Administration of the University of Jos. Dr Goyit is a member of the Nigerian Institute of Management (Chartered). He has interest in the areas of service quality, marketing, total quality management, entrepreneurship marketing/education among others.

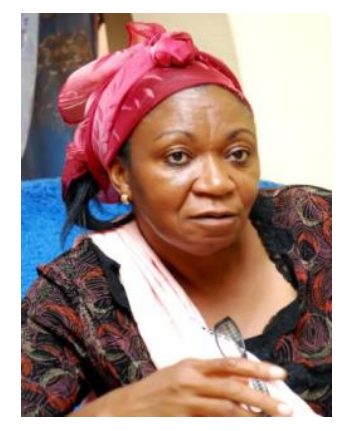

Professor Nmadu, Teresa M. (Mrs.) holds a PhD in Management from the University of Jos, Nigeria. Sheis a professor of human resource management. Professor Nmadu occupies a position of competence and prominence in the University of Jos. She has extensive experience in human resource management. She is currently the Deputy Vice Chancellor (Administration) of the University of Jos, Nigeria. Professor Nmadu has had numerous engagements in both the public and private sectors as well as NGOs. She has served in many capacities as Head of Department, Deputy Dean and Director of General Studies and Centre for Entrepreneurship Studies and she is a member of many chartered InstitutesHer areas of interest include human resource management, strategic management, entrepreneurship, women entrepreneurship, etc. 